\title{
Sites chosen by diapausing or quiescent stage quino checkerspot butterfly, Euphydryas editha quino, (Lepidoptera: Nymphalidae) larvae
}

\author{
Gordon F. Pratt $\cdot$ John F. Emmel
}

Received: 6 February 2009/Accepted: 8 June 2009/Published online: 26 June 2009

(c) The Author(s) 2009. This article is published with open access at Springerlink.com

\begin{abstract}
This study examines whether in nature endangered quino checkerspot (Euphydryas editha quino) larvae will return to diapause and if so where they choose to hide. Multiple years of diapause probably help larvae survive drought years and sites chosen have high survival value to the species. Ninety square meters of habitat were created by removing non native plants and replacing them with natives found at checkerspot occupied sites. During the 2005-2006 winter 1,000 post-diapause larvae were released. From these larvae 31 adults (20 males and 11 females) developed over a 2.5 month period (March 20-June 6) from 41 pupae. One chrysalis was parasitized by a parasitic wasp Pteromalus puparum (L.) in the family Pteromalidae, one was partially eaten by an animal, while the remaining eight pupae died of unknown causes. Thirty quadrats (1 square meter each) were cleared of vegetation, leaf and branch litter, rocks, and checkerspot larvae from July 5 to August 1, 2006. Forty-nine larvae were found that returned to diapause. Most larvae (31) chose to make shelters on California buckwheat, which is not a checkerspot food plant, two to five $\mathrm{cm}$ above the ground. One shelter had 22, another had seven, and two others had single larvae. Five of 10 larvae found in leaf litter below California buckwheat were crawling and not associated with shelters suggesting they had been dislodged from shelters. California buckwheat may be important in habitat restoration for the checkerspot, particularly at sites below 900 meters elevation where summer conditions are hot and dry. No
\end{abstract}

\footnotetext{
G. F. Pratt $(\bowtie)$

University of California, Riverside, CA 92521, USA

e-mail: gordon.pratt@ucr.edu

J. F. Emmel

26500 Rim Road, Hemet, CA 92544, USA
}

additional larvae were found the following spring, when they should have exited diapause. Therefore 910 (91\%) larvae were lost to some undocumented form of mortality.

Keywords Insecta - California buckwheat . Pteromalidae $\cdot$ Conservation $\cdot$ Restoration

\section{Introduction}

The quino checkerspot, Euphydryas editha quino (Behr), was at one time one of the most abundant southern California butterflies (Mattoni et al. 1997). As recent as 1977 there were quino checkerspot population explosions reaching nearly two orders of magnitude over normal densities (Murphy and White 1984). Checkerspot numbers according to Murphy and White (1984) reached hundreds of thousands at four sites. About 10 years later in the late 1980s when the checkerspot was petitioned for the endangered species list, it was already believed extinct. Fortunately, in the mid 1990s new quino checkerspot populations were discovered in southwestern Riverside County and later in southwestern and southeastern San Diego County (Mattoni et al. 1997).

Quino checkerspots have an interesting life history. They are univoltine with a late winter/early spring emergence and rarely observed at other seasons after high rainfall (Murphy and White 1984). Female checkerspots generally emerge 2-3 days after the first males and mating is immediate upon their emergence. Within a day the females oviposit clusters of one hundred or more eggs at the base of their annual food plants. These clusters are often on the most open exposed food plants. Because of the short life spans of the annual food plants the first clusters to be oviposited are the most likely to survive to diapause (Murphy and White 1984; Pratt 
et al. 2001). The egg clutch hatches within 2 weeks, the larvae create a protective silken shelter over the food plant, and they feed upon it until it dries out or is completely defoliated. The larvae leave the plant and search for additional resources until they are ready to enter diapause as third or fourth instar larvae. Once in diapause they remain until fall and/or winter precipitation brings up their annual food plants and at this time the post-diapause larvae either develop to adults or re-enter diapause a second or more years (Murphy and White 1984).

Despite past quino checkerspot abundance and extensive work on other populations of Edith's Checkerspot, very little was known of the butterfly's field biology. As an example, the checkerspot was believed to be restricted to below $910 \mathrm{~m}$ elevation. It is now known to occur continuously up to slightly above $1,515 \mathrm{~m}$ elevation (Pratt et al. 2001). Also quino checkerspot larvae were thought restricted to a single food plant, Plantago erecta E. Morris (Erect Plantain). Larval clusters were later found feeding upon as many as four new plant species in four genera: Plantago patagonica Jacq. (Patagonia plantain), Antirrhinum coulterianum Benth. (white snapdragon), Castilleja exserta (A. A. Heller) (purple owl's clover), and Cordylanthus rigidus (Benth.) Jepson (rigid bird's beak) (Pratt et al. 2001). An additional checkerspot food plant species and genus, Collinsia concolor E. Greene (southern Chinese houses), was identified during the 2008 season (Pratt and Pierce in press).

Most North American butterflies have biological adaptations that allow them to survive periods when there are little to no food resources (Scott 1979, 1986). Butterflies usually go through some quiescent stage (diapause) as eggs, larvae, pupae, or adults during which there is low to no measurable metabolism (Chapman 1971). Quino checkerspots diapause as larvae, but there is some question whether these dormant larvae are actually in diapause since they respond immediately to disturbance by crawling. They also start feeding after being exposed to a 10 day period of high humidity without even a cold period (Pratt personnel observation). Checkerspot larvae generally remain quiescent from May through January or February (Osborne and Redak 2000). This period can be extended when the food plant quality is not sufficient to support larval development (Murphy and White 1984; Mattoni et al. 1997; Emmel and Pratt personnel observation). Poor plant quality is usually a result of low precipitation and/or midwinter intervening hot dry periods.

Prolonged or multiple years of diapause is found in many Lepidoptera including the butterfly families: Pieridae, Papilionidae, Nymphalidae, and Lycaenidae (Scott 1979; Powell 1987; Emmel and Pratt personnel observation). The stage of prolonged diapause varies with species and largely ranges from different larval stages to pupae (Scott 1979). Of known moths and butterflies the yucca moth Prodoxus y-inversus (Riley), which diapauses as a mature larva, has exhibited the longest diapause period up to 30 years (Powell 2001). Prolonged diapause is most frequent in butterfly species that are adapted to areas with extremely variable precipitation (Scott 1979, 1986). The pupae of small blues in the Euphilotes genus, particularly ones adapted to annual buckwheats, can diapause for at least 5 years waiting for presumably the appropriate precipitation (Pratt and Ballmer 1987; Pratt 1988; Pratt and Emmel personnel observation). Even the Icarioides blue Icaricia icarioides (Boisduval), which has a number of endangered subspecies, has exhibited multiple years of diapause by entering a second year of diapause as third instar larvae (Emmel personnel observation). This behavior by the quino checkerspot as well as other members of Euphydryas checkerspots is used as an adaptation to survive seasons of low rainfall that produce poor plant resources (Singer and Ehrlich 1979; Ehrlich and Murphy 1981; Murphy and White 1984).

Since quino checkerspots spend most of their life in larval diapause, where they choose to hide during this period is extremely important for their survival. If these sites are not available, then quino checkerspots may not survive even a single generation. Despite their importance, very little is known of them other than observed under laboratory conditions. Larvae in captivity enter diapause on soil surface, under leaf litter, and up in plants several centimeters above the soil surface. But the choices made could be due to a smaller number of unnatural sites and temperature differences in captivity compared to field conditions. The purpose of this study was to examine natural habitat choices made by post diapause larvae that return to the dormant stage. There is controversy as to whether larvae will return to dormancy in nature, so this study will also examine the frequency of larvae that return to diapause for two or more seasons.

\section{Materials and methods}

A small number of quino checkerspot butterflies were observed on Vista Murrieta High School's property prior to construction. As part of mitigation the school was required to build an endangered butterfly captive breeding facility. An area adjacent to the facility was also provided to grow plants. This area was used to create an experimental habitat, which resembled a natural fragmented site with scattered native bushes, rocks, food plants, and other annuals growing on largely open soils. Quino checkerspot larvae were unlikely to have survived on site prior to habitat construction since it was completely bulldozed and all plants were removed. Also no larvae or adults were observed the following year after the school's construction 
in 2004. Some Plantago erecta seeds survived the bulldozing and sprouted on the outdoor habitat before any seeds were spread.

\section{Habitat construction}

Ninety square meters were cleared and kept clear of weeds, such as Erodium L'Hér. sp. (Storksbill), Brassica L. sp. (mustards), and non-native grasses and composites from late 2004 to 2006. The soil was compacted, watered, and various sized rocks were scattered. The following potential larval food plant seeds were spread: Plantago patagonica, Antirrhinum coulterianum, and Collinsia concolor from Anza, California, Plantago erecta from the Temecula area, Plantago elongata Pursh (elongate plantain) from San Diego vernal pools, Castilleja exserta from Wilson Valley, Riverside County, California, and Cordylanthus rigidus from Marron Valley, San Diego County, California. Collinsia heterophilla Graham (purple Chinese houses) seeds from Theodore Payne Foundation, Sun Valley, California, were from an unknown location. Castilleja exserta was also hydroseeded nearby during high school construction.

Potential quino checkerspot butterfly nectar source annuals developed on the habitat. Lasthenia californica Lindley (slender goldfields) from Wilson Valley, Chaenactis glabriuscula DC. (yellow pincushion) from Wilson Valley, and Phacelia minor (Harvey) (wild Canterbury bells) from Theodore Payne Foundation grew from hand spread seed. Additional annuals that developed on the habitat were Calandrinia ciliata (Ruiz Lopez and Pavón) (red maids), an Amsinckia Lehm. sp. (fiddleneck), and a Cryptantha Lehm. sp. Amsinckia menziesii (Lehm.) (common fiddleneck) and Lasthenia californica were hydroseeded near the habitat during school construction. Only the Cryptantha sp. which came up in 2005 did not come up in 2006. Other native annuals present at other quino checkerspot occupied sites came up naturally. The annuals that sprouted on the constructed habitat were a Plagiobothrys F. \& M. sp., two annual Lotus L. sp. [one was L. purshianus (Benth.)], dove weed (Eremocarpus setigerus Benth.), and tarweed (Hemizonia DC. sp.). Some dove weed was removed in 2005 to prevent it from becoming dominant. The lives of the food plant and nectar annuals were extended by watering once a week during periods of no rainfall.

California buckwheats (Eriogonum fasciculatum Benth.) were spaced out and planted. Most plants were sprouted 2 years earlier from Lake Skinner seed. One buckwheat was collected as a small bush from south of Anza. Two bushes developed naturally from seed dispersed from hydroseeded plants at the high school. These bushes differed somewhat in height, shade, and cover. The major perennial bushes other than California buckwheat were Lotus scoparius (Nutt. in T. \& G.) (deerweed) and Encelia californica Nutt. (California encelia). The E. californica was hydroseeded during school construction. California everlasting (Gnaphalium californicum DC.) seeded itself and formed a large annual or biennial.

Field collection of females

A review of the captive breeding methodology is found in quinocheckerspot.com. Much information can be learned from rearing endangered butterflies that will help in conservation. In order to reduce the negative effects of collecting upon field populations, female checkerspots were collected late in the season. Since the food plants are dying and desiccating, larvae from these females are unlikely to survive. Development time from freshly oviposited egg to late second instar, the earliest stage to enter diapause, generally takes about 4 weeks (Pratt and Emmel personnel observation). Larvae must feed before they can successfully enter diapause, while food plants do not live long due to dry conditions that follow winter/spring rains. So larvae from eggs oviposited first are most likely to enter diapause, while larvae from eggs oviposited last in the season are least likely to make it to diapause (Singer and Ehrlich 1979). Flower nectar is also reduced late in the season so older females usually have less resources to make egg clutches (Ehrlich and Murphy 1981). By feeding these older females a mixture of honey water (one to three), they will in captivity oviposit many more eggs than they would in nature. Survival of those larvae that hatch can be increased by feeding them laboratory grown plants.

\section{Captive breeding}

The larvae were reared to diapause, broken from diapause the following season, and reared to adults. Some females were mated to males from different parentage in the lab colony, while others in order to improve the genetics of the captive bred population were mated with field collected males. Adult emergence was timed to field populations and females were taken to the field where the source females were collected and mated with field collected males. For each lab reared female a male was carefully collected to prevent damage to legs, antennae, and wings and mated to the female in a cage. Once mated, the male was released back to the location at which it was collected. Lab reared males mated successfully 5 times in captivity and all matings were fertile, so these released males were probably capable of mating multiple times.

Larval diapause and release

Quino checkerspot larvae were broken from diapause by placing them on wet paper towels within Gladlock storage 
containers. The containers, with Penstemon Mitch. leaves placed on the bottom as food, were opened twice daily, eight to $16 \mathrm{~h}$ apart to reduce mold. The containers were cleaned after extensive feeding by larvae. After 10 days the larvae were put onto the created habitat. Only quino checkerspot larvae originally from Lake Skinner, Riverside County (13 km east of the study habitat) were used for this experiment; this ensured that any escaping adults were from a local checkerspot population. The 1,000 released larvae were as follows: 106 two year old larvae (all remaining larvae are one year old) from one female line released on 12 December, 2005, 85 larvae from a cross of female line 2 mated to a field collected male released on 14 January, 501 larvae (118 larvae from a cross of female line 2 mated to a field collected male, 107 larvae from a cross of female line 3 mated to a field collected male, 152 larvae from a cross of female line 4 mated to a field collected male, and 124 larvae from a 2005 field collected female number 2) released on 6 February, and 308 larvae (107 larvae from a cross of female line 4 mated to a field collected male, 109 larvae from a cross of female line 2 mated to a field collected male, and 92 larvae from a cross of female line 3 mated to a field collected male) released on 7 February, 2006.

The released larvae fed upon annual food plants on the created habitat and were allowed to re-enter diapause. Twice a week, February through April, all but one last instar larvae were found and transferred to a field cage placed over flats of Plantago erecta. Once quino checkerspot larvae become last instars they are believed incapable of returning to diapause, therefore isolating last instar larvae minimized escaping adults.

Survey methods (collections from 30 quadrats)

From July 5 to August 1, 2006 leaf litter, wood chips, branches, and rocks were cleared from 30 quadrats. Each quadrat was one square meter in size. Rocks were removed first and carefully checked for diapausing larvae. With pruning sheers branches of all bushes were collected and placed in bags. The reason for collecting the branches was diapausing larvae were small and easily dislodged. Before collecting the main stalk of each bush, it was carefully checked and the leaf litter beneath the bush was collected. We compared with chi-square analysis the numbers of larvae against those expected on substrates if larvae were randomly distributed.

\section{Results}

Most larvae did not leave the created habitat. Some larvae $(>10)$ were even observed crawling directly back to the created habitat. On the other hand, one larva was observed over $10 \mathrm{~m}$ away on blacktop and was unlikely to find its way back.

A few rocks, wood chips, and leaf litter were searched in early January, 2006. About four or five larvae immediately returned to diapause under rocks and in leaf litter. Approximately a dozen larvae were found hiding while either not feeding or molting to the next instar. Larvae in diapause were identified from hiding larvae by a silken shelter, a characteristic curled " $\mathrm{c}$ " shape, and remaining in the same location for several days. The two or three larvae that immediately re-entered diapause under rocks either moved or died sometime before collection of the quadrats in early July to early August.

Larvae in diapause were not distributed on substrates of quadrats randomly (Table 1). Thirty-one larvae were found in shelters on California buckwheat, Eriogonum fasciculatum, while five larvae were found wandering in leaf litter below them. All larvae on California buckwheat were within shelters in shaded cavities where branches separated from the main trunk. Four of nine buckwheat cavities had diapausing larvae: one had 22, another had seven, and the other two had one each. No larvae were found on buckwheat branches. The five larvae observed crawling beneath the buckwheat were likely dislodged from branches during sampling, since they were observed beneath bushes after branches were pruned. Forty-six (94\%) of the 49 larvae in diapause were found on the nine quadrats which had a California buckwheat plant.

Diapausing quino checkerspot larvae were found on two additional plant species: Gnaphalium californicum (two on one and three and two on another) and Amsinkia sp. (1) (Table 1). One cluster of three larvae found on the Gnaphalium was found $20 \mathrm{~cm}$ above the soil surface. The remaining 10 larvae were found in leaf litter. These larvae were found in the shade of bushes, particularly California buckwheats and some California encelia. Five larvae in leaf litter were actively crawling, while the other five larvae were in shelters within curled leaves. The leaves chosen were brown and thick and were likely of Phacelia minor. The leaves had curled in such a way that they were completely closed. Most leaves silkened in the same way were often inhabited by spiders.

Other quino checkerspot larval behaviors were observed in this study. Post-diapause larvae, though the source population fed exclusively upon Plantago erecta, fed readily upon Antirrhinum coulterianum (>6), Plantago patagonica $(>10)$ and Plantago elongata (1). Once A. coulterianum and Plantago patagonica plants began sending up flower stalks, they became less attractive to feeding by post-diapause larvae. They fed preferentially on freshly sprouted Plantago erecta over other food plants. On 2 March, 2006, a larva searched for a pupation site; it stopped at the northeast side of a rock and stretched up and 
Table 1 One-way chi-square analysis of substrate-use by quino checkerspot larvae

\begin{tabular}{|c|c|c|c|c|c|c|}
\hline Substrate & $\begin{array}{l}\text { \# } \\
\text { Quads }\end{array}$ & $\begin{array}{l}\text { Proportion with } \\
\text { Substrate }\end{array}$ & $\begin{array}{l}\text { Obs. }^{\text {a }} \text { \# } \\
\text { Larvae }\end{array}$ & $\begin{array}{l}\text { Exp. }^{\mathrm{b}} \text { \# } \\
\text { Larvae }\end{array}$ & $\begin{array}{l}\text { Chi-square } \\
\text { Obs. vs Exp. }\end{array}$ & Dev. \\
\hline Leaf litter & 30 & 0.170 & 10 & 8.35 & 0.3 & 1.6 \\
\hline Rocks & 26 & 0.148 & 0 & 7.24 & 7.2 & -7.2 \\
\hline Eriogonum fasciculatum & 9 & 0.051 & 31 & 2.51 & 324.0 & 28.5 \\
\hline Gnaphalium californicum & 3 & 0.017 & 7 & 0.84 & 45.5 & 6.2 \\
\hline Conyza canadensis & 24 & 0.136 & 0 & 6.68 & 6.7 & -6.7 \\
\hline Chaenactis glabriuscula & 26 & 0.148 & 0 & 7.24 & 7.2 & -7.2 \\
\hline Plantago species & 17 & 0.097 & 0 & 4.73 & 4.7 & -4.7 \\
\hline Amsinkia species & 15 & 0.085 & 1 & 4.18 & 2.4 & -3.2 \\
\hline Encelia californica & 16 & 0.091 & 0 & 4.45 & 4.5 & -4.5 \\
\hline Lotus scoparius & 6 & 0.034 & 0 & 1.67 & 1.7 & -1.7 \\
\hline Phacelia minor & 4 & 0.023 & 0 & 1.11 & 1.1 & -1.1 \\
\hline Total & 176 & 1 & 49 & 49 & $405.3^{\mathrm{c}}$ & 0.0 \\
\hline
\end{tabular}

$P<0.001$

${ }^{\text {a }}$ Obs observed

${ }^{\mathrm{b}}$ Exp expected

c $d f=10$

down and back and forth. A few moments later it was observed exhibiting the same behavior at a nearby rock shadow, which covered a larger area with more annuals. It pupated at this site. Twenty-three days later the pupa was found on the ground near the pupation site, it was divided in half, and left mostly uneaten.

Approximately fifty mature larvae were placed in a field cage, where they were allowed to feed until they pupated. Forty pupae were collected from the field cage 2 days after each one pupated and placed in a cage indoors by a southfacing window where adults were allowed to emerge. This collection minimized escape, since adults that eclose in the field cage could have escaped when opened outdoors. One pupa produced parasites that were identified as Pteromalus puparum (L.) which is a parasitic chalcid wasp in the family Pteromalidae. Twenty males and 11 females of quino checkerspots emerged from thirty-nine pupae.

Other larvae found on California buckwheat (Eriogonum fasciculatum) were one Euphilotes bernardino (Barnes and McDunnough), three Apodemia virgulti (mormo) virgulti (Behr), one geometrid moth, and three or four microlepidoptera. The Euphilotes bernardino larva was finished feeding and was searching for a pupation site. The Apodemia virgulti larvae were sitting inside shelters on the underside of buckwheat branches. The purplish brown microlepidoptera larvae were probably in diapause (or a quiescent state) and in silken webs at the base of a bush.

Additional plants found on the quadrats not listed in Table 1 because of low numbers and lack of quino checkerspot larvae were: (the number following the plant species in parenthesis is the number of quadrats the plant was found on) Hemizonia DC. sp. (4), Camissonia robusta Raven (1), Centaurea L. sp. (3), Lotus purshianus (4), Rumex salicifolius J. A. Weinm. (1), Antirrhinum coulterianum (2), Microseris douglasii (DC.) (1), Baccharis salicifolia (Ruíz Lopez \& Pavón) sp. (1), Lasthenia californica (2), Rafinesquia californica Nutt. (1), Chenopodium L. sp. (1), Eremocarpus setigerus (15), Brassica sp. (1), and grass sp. (8). Most of the annuals were poorly represented because most had dried up and disappeared.

\section{Discussion}

Prolonged diapause can add a level of complexity to butterfly conservation. Butterflies can remain in diapause for multiple years as "seed banks" of diapausing larvae or pupae. Therefore observed numbers of adults during monitoring do not necessarily reflect how poorly or how well the species is doing. The endangered Palos Verdes Blue Glaucopsyche lygdamus palosverdesensis Perkins and Emmel, for example, which had adult numbers drop dangerously low during monitoring at the Defense Fuel Support Point in San Pedro, California in 2003 (peak of 4), exhibited its highest numbers the following year (peak of 43 ), indicating that a large number of pupae remained in diapause (Longcore 2003; Pratt 2004). A similar observation was exhibited with the quino checkerspot in the San Diego area. In the winter/spring of 1977 an outbreak of checkerspot larvae completely defoliated the food plant Plantago erecta so there was no food for prediapause larvae, yet the following season produced normal levels of 
food plants and quino checkerspots (Murphy and White 1984).

Genes involved in prolonged diapause need to be maintained in captive reared populations of endangered butterflies since prolonged diapause is important in long term survival in nature. Without these genes, butterflies released after habitat restoration will not survive through extremely dry winter/springs or other disasters that eliminate all progeny during a single season. Unfortunately preserving genes important in prolonged diapause is not easy in captive rearing since the procedures used to increase butterfly numbers often selects for those that do not diapause multiple years. For instance butterflies that develop the first year of captive rearing are ones that did not go through multiple years of diapause. If these butterflies are mated with each other to increase population numbers this could select for lines that are not adapted to long term diapause. Quino checkerspots that take multiple years to develop in captivity should be selected and mated with those that take 1 year and others that take multiple years to mature.

There has been little research on the dormant stage of quino checkerspots, despite most of their time being spent in this stage in nature (Mattoni et al. 1997; Osborne and Redak 2000). The earliest seasonal observations of quino checkerspot larvae at Lake Skinner were groups of larvae at margins of dense grass and shrub cover, which later separated by random dispersal (Osborne and Redak 2000). These observations suggest larvae diapaused under or within bushes or grass clumps. Larvae of other Euphydryas editha subspecies have been field collected but exactly where they were found was not reported (Singer and Ehrlich 1979). The weights of these larvae suggest some diapaused one summer through winter, fed the following spring, grew some, and returned to a second year of diapause (Singer and Ehrlich 1979).

Dormant stage or diapausing quino checkerspot larvae were found in four different structure sites in the following order: California buckwheat (Eriogonum fasciculatum), leaf litter, California everlasting (Gnaphalium californicum), and fiddleneck (Amsinkia species). Most larvae were observed at the trunk of California buckwheat, which was interesting since buckwheat is not a food plant for the quino checkerspot. The next most frequent site was leaf litter, but half of these larvae were either moving or outside of a shelter, so they were likely not dormant in leaf litter and probably dislodged from shelters on buckwheat branches. The next most frequent site was California everlasting, Gnaphalium californicum. Because of low numbers of this plant on the 30 quadrats, its significance is in question. There was only one quino checkerspot larva found in the basal leaves of Amsinkia; these leaves were found on 15 of the 30 quadrats.
From a survey to define characteristics that identify quino checkerspot habitat, one non-food plant California buckwheat (Eriogonum fasciculatum) was found at all checkerspot occupied sites in southern California (Pratt 2001). This plant was present at more occupied sites then even the main food plant, Plantago erecta. California buckwheat indicating checkerspot habitat was controversial since it was common throughout much of southern California (Hickman 1993) and there was no explanation why this buckwheat would indicate habitat. It was argued that California buckwheat was found at all checkerspot habitats just because it was very common throughout southern California. This buckwheat is not a food plant and flowers of these plants are not important food sources for adults, so there was no reason it would be important for the checkerspot's survival. But even the edges of checkerspot habitat are often better defined by the buckwheat than actual quino checkerspot food plants, particularly since the food plants are small annuals, vary at different sites, and are not visible most of the year.

California buckwheats form a shady somewhat humid habitat by holding their leaves throughout most of the year. As a comparison California encelia (Encelia californica) and deerweed (Lotus scoparius) leaf out and bloom after fall and winter rains and drop their leaves by mid spring to early summer. In addition California buckwheats grow by branching from a thickened trunk twisting in such a way that creates a shaded cavity deep within the bush. The importance of California buckwheat for quino checkerspot diapausing larvae could be the reason for its presence at all occupied sites below a thousand meters elevation. Higher humidity and cooler temperatures provided by these plants may increase checkerspot larval survival through the hot dry southern California summer.

California everlasting could be a good site for diapausing larvae, but these sites were within the shade of California buckwheat, so buckwheat may have played a greater role in diapause choice. California everlasting is not present at many quino checkerspot occupied sites. Although the everlasting is either an annual or biennial, it has thick leaves that turn dark brown, curl, and are held up above the hot ground. The dead plant also lasts through the summer.

Over 250 Conyza canadensis (L.) Cronq. plants were surveyed by this study. This annual remains alive throughout most of the summer and has leaves at the base that could have made a good diapause site for quino checkerspot larvae. In spite of all these surveyed plants, no quino checkerspot larvae were found associated with $C$. canadensis. Perhaps shade is more important and they did not have enough shade or protection for quiescent state larvae as do the everlasting and buckwheat.

Two quino checkerspot larvae were observed entering a quiescent state between overhanging rocks in January. It 
was surprising they were not observed in early July to early August beneath or between rocks. During July in Marron Valley (a checkerspot occupied site) soil and rock temperatures were close to $70^{\circ} \mathrm{C}$, even though air temperatures were nearly 30 degrees lower. These soil and rock temperatures were rather high for survival and a larva may have to either move to a cooler site such as beneath bushes or die from overheating.

No larvae were observed feeding after early April. Quino checkerspot larvae that were not last instar probably returned to a quiescent state. This was surprising since there were extensive cool rains that came in March and April, yet Plantago did not sprout from these rains. Perhaps Plantago seeds require a specific photoperiod to sprout. If seed sprouting occurs only during short days, longer day lengths in April may be too long for Plantago seeds to sprout.

Laboratory results predict after larval mortality, $50 \%$ or more of those surviving should return to a quiescent state, while the remainder will become adults. For instance, from 789 postdiapause larvae from 8 different Lake Skinner female lines in 2007 there was a total mortality of $37 \%$, while $72 \%$ of the remaining larvae returned to diapause (Pratt 2007). An experiment of 630 postdiapause larvae from a Lake Skinner female line in 2008 gave 36.5\% mortality, while $49 \%$ of the remaining larvae returned to diapause (Pratt and Switzer 2008). It is not surprising that field mortality is over double that of laboratory. The 49 larvae found dormant in summer represented about $54 \%$ of the remaining larvae, which was close to expected. Since the habitat was watered frequently, larval numbers that return to diapause is probably much higher most seasons in nature due to drier conditions.

The sampled area represented about $33 \%$ of the total constructed habitat, so if the whole area had been surveyed the total dormant larvae could have increased to 150 . But no larvae were observed the following season, which would be expected if diapausing larvae remained in the habitat. Mortality could have been around $91 \%$ considering there were probably many larvae preyed upon, parasitized, and other factors. This mortality was not much higher than expected since mortality for other Euphydryas editha populations were $74 \%$ (on Collinsia torreyi A. Gray) and 91\% (on Pedicularis semibarbata A. Gray) during postdiapause larval development (Moore 1989).

Secondary Plantago sprouting from later precipitation may be important for development of quino checkerspot larvae to adults. These fresh young plants were preferred by later instar quino checkerspot larvae. Larvae that start feeding on food plants that are in the process of blooming may stimulate them to return to a quiescent state. But if a larva reaches the last instar by feeding on freshly sprouted food plants, it may still pupate even though it feeds on plants that are in the process of blooming.

\section{Restoration}

Up to this point there has been emphasis on increased annual and reduced perennial plants within quino checkerspot habitat. This is due to quino checkerspots preferring to fly over nearly barren ground and larvae feeding and pupating upon open habitats that favor development of annuals (Osborne and Redak 2000). This larval release suggests shade may be important in their survival. Although this part of the habitat may represent a small portion, bushes or other structures that provide shade throughout the summer may be important for high long term larval survival. California buckwheat could be an important source of shade since this bush keeps its leaves throughout the summer unlike other perennials found in occupied checkerspot sites.

Plantago elongata, which occurs around vernal pools in the San Diego area, could be an important food plant for late instar checkerspot larvae. At least one larva was observed feeding upon this annual even with multiple choices. Greater food plant choices could improve habitat quality at occupied sites. Larvae fed upon multiple annuals, even though they came from a population associated with a single food plant. Although these plants may not naturally occur together, there is now far less checkerspot habitat, so long term survival may depend on improved habitat quality. Food plants may respond to seasons differently, some plants may be favored from early precipitation, while others from later rains. A greater variety of food plants may mean at least one food plant will be available most seasons.

Acknowledgments We thank Cecilia Pierce, Jessica Turner, and Martha Cecilia Alvarado Franco for all of their help with the research for this study. Roger Burks identified the chalcid wasp. We also thank Mike Singer, Camille Parmesan, Richard Stouthamer, Robert Luck, Greg Ballmer, Edith Allen, Alison Anderson of United States Fish and Wildlife Service, and Dave Mayer of California Fish and Game for their support and helpful discussions. Andy Sanders identified some of the plants. Special thanks are given to William Wiesenborn for his help with the statistics of this study and Vista Murrieta High School for providing the facility and space for the research. The research was supported by a grant from United States Fish and Wildlife Service.

Open Access This article is distributed under the terms of the Creative Commons Attribution Noncommercial License which permits any noncommercial use, distribution, and reproduction in any medium, provided the original author(s) and source are credited.

\section{References}

Chapman RF (1971) The insects: structure and function. Elsevier, New York, p 819

Ehrlich PA, Murphy DD (1981) The population biology of checkerspot butterflies (Euphydryas). Biolgisches Zentralblatt 100: 613-629 
Hickman JC (1993) The Jepson manual: higher plants of California. Eriogonum Wild Buckwheat, pp 860-883. University of Califonia Press, Berkeley Los Angeles, p 1400

Longcore T, Mattoni RHT (2003) Final report for 2003 Palos Verdes Blue Butterfly Year 2002 Adult Surveys on Defense Fuel Support Point, San Pedro, California. Los Angeles: The Urban Wildlands Group (Defense Logistics Agency Agreement \# N68711-03-LT-C3003), p 12

Mattoni R, Pratt GF, Longcore TR, Emmel JF, George JN (1997) The endangered quino checkerspot butterfly, Euphydryas editha quino (Lepidoptera: Nymphalidae). J Res Lepidoptera 34:99-118

Moore SD (1989) Patterns of juvenile mortality within an Oligophagous insect population. Ecology 70:1726-1737

Murphy DD, White RR (1984) Rainfall, resources, and dispersal in southern populations of Euphydryas editha (Lepidoptera: Nymphalidae). Pan-Pacific Entomologist 60:350-354

Osborne KH, Redak RA (2000) Microhabitat conditions associated with the distribution of post-diapause larvae of Euphydryas editha quino (Lepidoptera: Nymphalidae). Ann Entomol Soc Am 93:110-114

Powell JA (1987) Records of prolonged diapause in Lepidoptera. J Res Lepidoptera 25:83-109

Powell JA (2001) Longest insect dormancy: Yucca Moth larvae (Lepidoptera: Prodoxidae) metamorphose after 20, 25, and 30 years in diapause. Ecol Popul Biol 94:677-680

Pratt GF (1988) The evolution and biology of Euphilotes biotypes. Unpublished doctoral dissertation, University of California, Riverside, p 653

Pratt GF (2001) The Quino checkerspot: its biology and life history final report. Report published through the University of
California for the California Fish and Game Account Title CDFG FG7182ES Luck 6/98, p 96

Pratt GF (2004) Final report for Palos Verdes Blue Survey 2004 on defense fuel support point San Pedro, California (Defense Logistics Agency Agreement \# N68711-04-LT-A0003), p 34

Pratt GF (2007) Captive breeding of the Quino checkerspot at the Murrieta high school facility in 2006-7. Entomology Department, University of California, Riverside, CA 92521. Report provided to USFWS at Carlsbad, California, p 9

Pratt GF, Ballmer GR (1987) The phenetics and comparative biology of Euphilotes enoptes (Boisduval) (Lycaenidae) from the San Bernardino Mountains. J Res Lepidoptera 25:121-135

Pratt GF, Hein EW, Krofta DM (2001) Newly discovered populations and food plants extend the range of the endangered quino checkerspot butterfly, Euphydryas editha quino (Nymphalidae) in Southern California. J Lepidopterists Soc 55:176-178

Pratt GF, Pierce CL (in press) A new larval food plant, Collinsia concolor, for the endangered quino checkerspot, Euphydryas editha quino. J Lepidopterists Soc

Pratt GF, Switzer C (2008) Captive breeding 2007-8. Entomology Department, University of California, Riverside, CA 92521. Report provided to USFWS at Carlsbad, California, p 3

Scott JA (1979) Hibernal diapause of North American Papilionoidea and Hesperioidea. J Res Lepidoptera 18:171-200

Scott JA (1986) The butterflies of North America, a natural history and field guide. Stanford University Press, Stanford, p 583

Singer MC, Ehrlich PR (1979) Population dynamics of the checkerspot butterfly Euphydryas editha. Fortschritte der Zoologie $25: 53-60$ 